\title{
Development of Corporate Bond Market in India - Challenges and Reforms
}

\author{
Varun Dawar \\ Professional Affiliation, Senior Manager-Treasury, Max Life Insurance Ltd.
}

\begin{abstract}
Corporate Bond market in India, unlike developed and other Asian counties, is relatively underdeveloped both in terms of depth and liquidity. Given the excessive reliance of corporates on bank funding, credit risks are fairly concentrated within the banking sector. Also the share of corporate issuances is abysmally low when compared to the same in government securities market. Globally bond markets are much bigger than the size of equity market whereas in India the size of corporate debt market has remained insignificant in comparison to that of equity. Although the equity markets in India have grown at a brazen pace fuelled by reforms and participation, bond markets have lagged and continue to remain plagued with various issues and unfavorable policy environment. This paper reviews the current state of corporate bond market in India and discusses issues and policies that can help further deepen and improve liquidity in corporate bond market.
\end{abstract}

Keywords: India, bond market, structure, issues, suggestions

\section{Introduction}

Capital market system in any country develops only when both equity and debt markets assumes depth and liquidity. World over, debt markets (especially corporate bond segment) has become much larger in size compared to traditional banking and equity sources of financing. For example in US, where the corporate bond market is most developed, bond market financing overtook borrowing from domestic banks long ago and currently stands $~ 130 \%$ of GDP. Even in Asia, if we look at Hong Kong and Korea, the similar ratio is $40 \%$ and $60 \%$ respectively. In India, however, although the equity markets have grown at a brazen pace fuelled by reforms and participation, bond markets are still underdeveloped. Corporate debt as \% of GDP in India stands at $6 \%$, which is abysymally low, both in comparison to developed markets and Asian peers. Also given the excessive reliance on bank funding, credit risks have become concentrated in the economy.

Indian bond market also has disproportionate share of Government of India (GoI) bonds compared to corporate issuances. For at the end of FY11, in terms of size the Indian corporate bond market stands $\sim$ INR 8895 billion which is mere $31 \%$ of Government of India (GOI) outstanding issuances ( 28,427 billion).

\section{International Development Of Corporate Bonds Market}

Internationally, the development of corporate bond markets has generally followed a similar pattern. In early stages of development, bank lending assumes central role of funding in the economy. However, as economy develops and reforms happen, bond market financing overtakes borrowing requirements of corporates. Also in countries, where corporate bond markets have developed in more recent decades have seen an emergence of an important determinant of availability of structured products. Structured financial products, such as mortgage and asset backed securities, bridge an important gap of that of credit quality of bonds that investors would like to hold and the actual credit quality of potential borrowers.

\section{Growth Of Indian Corporate Bonds Market}

The size of the Indian corporate bond market has grown to INR 8895bn with annual gross issuances doubling from INR 1.1trillion in Mar-07 to INR 2.3 trillion in Mar-11 on the back of number of reforms initiated by SEBI and RBI. Some of them include compulsory reporting and settlement of trades through National Securities Clearing Corporation (NSCCL) or the Indian Clearing Corporation (ICCL) of trades, reduction of stamp duty on corporate bonds and laying down the disclosure norms for public issues. One of the major investor concern of counterparty risk has been to a large extent addressed through establishing Delivery vs Payment (DVP) settlement by a central clearing agency. This has encouraged more companies to issue bonds and helped in better price discovery. 
The reforms timeline in corporate bond market in India started in 1992 has picked up pace only in last 34 years

1992: Government abolished the ceiling on the interest rate that erstwhile Controller of Capital Issues used to stipulate for issuance of corporate debentures

1994: NSE started trading in debt instruments through its WDM segment. However, WDM has been mostly used as a reporting platform for the deals on the OTC market. The WDM segment of BSE commenced operations in 2001.

2007: BSE and NSE set up reporting platform to capture trading data of corporate bonds. SEBI made regulator for primary and secondary market. Use of electronic payment facility for coupon and redemption started. Disclosure norms for listed bonds rationalized. Shut period in corporate bond is reduced.

2008: Listed corporate bonds made exempt from TDS (Tax deducted at source)

2009: Corporate Bond settlement through NSCCL. This has removed much of the counterparty risk from the system and made the settlement procedure more robust. FII limit in infrastructure bonds announced. First corporate bond repo trade.

2010: First public issue of non-convertible debt security. Compulsory clearing and settlement of all trades through centralized clearing houses.

2011: SEBI formalized infrastructure bond guidelines for FIIs. RBI eases norms for FII investment in infrastructure bonds. Proposed introduction of CDS on corporate bonds.

\section{STRUCTURE OF INDIAN CORPORATE BONDS MARKET}

\section{1) Issuers}

The major issuers of corporate bonds in India, as in the case of other developed markets, are private sector corporate, public sector undertakings, financial institutions, banks and medium and small companies. The top ten issuers in India comprise about $41 \%$ of total bond issuances in India (Table 1).

a) Bonds issued by Public Sector Undertakings (PSUs): PSUs are the largest and most active corporate bond issuers in India. The largest issuers (in terms of bond outstanding) are Power Finance Corporation (PFC), Rural Electrification Corporation (REC), National Bank for Agriculture \& Rural Development (NABARD), LIC Housing Finance and India Railway Finance Corporation (IRFC) and SAIL (Steel Authority of India Limited).

b) Bonds issued by Non-Banking Finance Companies (NBFCs): The second category of issuer of bonds comprises of Non-banking finance companies. The major private NBFC issuers are Housing Development Finance Corporation (HDFC), LIC HF, Infrastructure Development Finance Corporation (IDFC) etc. They issue senior as well as subordinated bonds.

Table 1: Top 10 issuers- Outstanding Corporate Bonds

\begin{tabular}{|l|c|}
\hline INR Billion & Total O/S \\
\hline Issuer & 630 \\
Power Finance Corporation & 469 \\
Housing Development Finance Corporation & 454 \\
Rural Electrification Corporation & 345 \\
National Bank For Agriculture and Rural Development & 313 \\
IDBI Bank Limited & 298 \\
India Railway Finance Corporation & 298 \\
LIC Housing Finance & 297 \\
State Bank of India & 282 \\
Power Grid Corporation of India & 270 \\
ICICI Bank & $\mathbf{3 6 5 6}$ \\
\hline Total of above issuers & $\mathbf{8 8 9 5}$ \\
\hline Total Corporate bonds O/S in India & $\mathbf{4 1 \%}$ \\
\hline Top 10 Issuers as \% of total & \\
\hline
\end{tabular}

Source: NSDL 
2) Investors

The main investors in the corporate bond market are, banks, insurance companies, provident funds and mutual funds. Mutual funds are primary investors in short dated paper and their investment pattern is primarily guided by growth of AUM's. Life insurance players on the other hand are buyers of long tenure paper given their asset liability structure and constant stream of renewal money. Banks investment in debt market is primarily in sovereign securities guided by mandatory SLR requirements.

FII as an investor category has constantly seen increase in opening up of limits for corporate bonds by SEBI. The current permissible limits and utilized amounts currently are as follows:

Table 2: Permissible Limits and Utilized Amounts - Outstanding Corporate Bonds

\begin{tabular}{|l|c|c|c|}
\hline & Amount & Utillization & Limits available \\
\hline As on Dec 2011 & $\begin{array}{c}\text { USD } \\
\text { billion }\end{array}$ & USD billion & USD billion \\
\hline Government debt & 15 & 11 & 4 \\
Corporate Bonds & 20 & 14 & 6 \\
Infrastructure (Debt Mutual Funds) & 3 & 0 & 3 \\
Infrastructure (Lock in 1 year) & 5 & 1.5 & 3.5 \\
Infrastructure (Lock in 3 year) & 17 & 0.1 & 16.9 \\
\hline
\end{tabular}

Source: $S E B I$

III. Issues Of Concern - Limiting The Further Development Of Corporate Bonds Market

1. Inadequate Liquidity: In India, secondary corporate bond market has tended to be illiquid given the buy and hold strategies followed by most institutional participants, lack of proper market infrastructure and the inability of small- and medium-size enterprises to access the debt markets. As a result, the turnover in corporate bond segment is miniscule compared to Government securities market (Turnover in Corporate bond segment has been $10 \%$ of turnover in Government securities market over the past few years).

2. Lack of Risk management (Derivatives) market: One of the main reasons for Indian corporate bond market to have failed to pick up is absence of interest rate/ credit derivatives which can efficiently transfer the risks arising out of interest rate movements and default probabilities. This has resulted in limited participation of banks in interest rate futures and swap markets and hence derivatives market in corporate bonds has failed to pick up. Also the CDS guidelines for corporate bond issued by RBI lately will be slow to take off given the restriction on participation and absence of central counterparty.

3. Higher rated Companies dominate Corporate issuance: In Indian corporate bond markets almost $70 \%$ of the bonds outstanding by value are rated AAA. This indicates that the number of sub investment grade issues is minimal and the proportion below AAA is small. Given the fact that only the largest corporations are likely to achieve an AAA rating, others are thus excluded from the bond market and obliged to rely on bank finance.

4. Private Placement issues: Small and medium corporate issuers generally raise resources through the private placement route given the cost considerations, ease of issuance, greater institutional demand and less retail interest. This leads to creation of multiple small issuances, which results in fragmentation and a deterrent to liquidity. In India, over $95 \%$ of issuances are through private placements.

5. Absence of Longer maturity Bonds: Given the underdeveloped structure of Indian corporate bond market, the term structure (Asset Liability management) needs of investors such as Insurance companies are not met. The longest maturity bond available in Indian corporate bond market is of 25 years tenure whereas given the liabilities structure of long term investors require higher tenure bonds so as to mitigate the reinvestment risk in their portfolio. This serves as big lacunae in participation of long-term investors in corporate bond market vis-àvis government securities market.

6. Tradability/Liquidity of Zero coupon bonds: Given the asset liability structure and need for mitigation of reinvestment risk, low liquidity of zero coupon bonds inhibits long term investors to adequately hedge/cover asset liability mismatch.

7. Corporate bonds repo: Corporate bonds have been made eligible for undertaking repos with maturity of repo ranging from 1 day to 1 year. However this market has failed to take off given that repos are permitted only 
in instruments having an original / residual maturity of 1 year (bulk of the activity happens in the less than 1 year segment).

8. Lack of bonds issues database: In Indian market, there is no single database which captures the issuance of corporate bonds as also the credit rating actions affecting those bonds. Even statistics provided by SEBI/RBI are only restricted to new issuances and does not cover credit events or total outstanding bonds.

9. Lack of universal conventions: Globally bond market conventions such as standardized day count in lieu of calculation of accrued interest have facilitated the smooth trading of corporate bond markets and reduce the time needed in negotiation. In Indian corporate bond market, absence of such conventions has constrained the development of corporate bond market given the difficulty in terms of negotiation given the practice of different day counts.

\section{Suggestions And Recommendations For Development Of Corporate Bond Markets In India}

1. FII participation: The prevailing withholding tax (WHT) on interest earned on corporate bond holdings acts as a deterrent for most FIIs (Foreign Institutional Investors). Given that most of the long-term investors internationally are non-tax paying entities (like pension funds), they are not able to set-off/tax credits in their home jurisdiction and thus WHT results in significant lowering of investment returns. To rectify this anomaly and encourage more active participation from FIIs, exemption of WHT on interest earned on their corporate bond holdings in India should be discovered.

2. Risk Management: To enable FIIs to manage their currency risk in respect of their investment in Corporate Bonds, they should be allowed rebooking of Foreign exchange hedges and also hedging of expected coupons over and above their initial investment amount in corporate bonds. This would enable derisking of future cash flows and thereby wider participation corporate bond market.

3. PF participation: Presently PF (Provident Funds) trusts are not allowed trading in their portfolios, which leads to reduction in floating stock in the market, thereby impacting the secondary market liquidity for bonds. Hence, allowing PFs to churn their portfolios for maximization of returns would lead to deepening of corporate bond markets. Also PFs should be allowed greater allocation towards bonds issued by private sector.

4. Retail participation: To ensure wider retail participation, particularly the High net worth individuals, the face value of bond instruments may be reduced from Rs. 10 lakhs currently to Rs. 50,000 or Rs. 1 lakh. Also fiscal incentives should be on listed corporate paper such as waiver of tax on capital gains or interest Income, so as to create level playing field with investments in equity.

5. Market trading platform infrastructure: In line with integrated trading and settlement system that exist for Government securities (NDS), similar platform is proposed for corporate bonds to ensure anonymous trading and efficient trading of securities among market participants. Furthermore market participants must be allowed to take intraday calls (moving from DVP I to DVP III system), on similar lines with Government securities.

6. Reporting of Trades: As per prevailing regulations, only entities regulated by RBI and SEBI are required to report and settle their trades through the exchange-based or FIMMDA platforms. To ensure efficiency and transparency in flow of market information, it should be made mandatory for all participants to report all trades.

7. Corporate Bonds Repo: As per RBI guidelines, repo in corporate bonds can be done only in instruments having an original / residual maturity of 1 year. This has resulted in lackluster volumes in corporate bonds repo market given the fact that bulk of the activity happens in the less than 1 year segment (as mutual funds are significant player in the corporate bond market). To kickstart the corporate bond repo market, instruments having original / residual maturity of less than $1 \mathrm{yr}$, say with a residual maturity of at least 1 month should be allowed for repo. Also, CP and CDs should be considered as eligible instruments for repo.

8. Bank participation: Banks should be allowed to run trading positions in corporate bonds and such trading book positions may be considered for certain relaxation from overall single entity borrower limits. This would help smaller banks to participate in the corporate bond market actively, who are currently constrained by such limits. The regulator should also consider exempting borrowings through repo in corporate bonds from CRR/SLR requirements in line with repo transactions in Government securities. This would further help kickstart the repo market for corporate bonds by encouraging participation from various banks. 
9. Credit Enhancement: In India where there is a lacuna in terms of long term funds for Infrastructure sector, domestic corporate bond markets can play a significant role in its development. To address this lacuna, the regulator should allow banks and domestic financial institutions to extend credit enhancement for bonds and debentures issued in the onshore market by companies engaged exclusively in the development of infrastructure or by the Infrastructure Finance Companies, subject to such instruments having an average maturity of at least 5 years. Also, such instruments should not have any prepayment and call / put options before 5 years.

10. Universal Conventions Currently there are no standardized conventions with respect to day count, face value and shut periods which leads to confusion among participants with regards to deals reported. Standardization of above parameters would help in improving secondary market liquidity and also ensure efficient flow of information and trade reporting.

11. Issuance patterns: Currently, reissuance of corporate bonds is governed by funding and timing requirements of issuers, thereby resulting in variance in coupons and dates of issuances. Reissuance of corporate bonds should be allowed under the same ISIN (International Securities Identification Number), thereby ensuring consolidation of issuances. This will ensure large floating stock of each issuance thereby improving secondary market liquidity and better price discovery mechanism. Also the shut period of bonds should be reduced from 15-30 days currently to 1 day in line with Government securities market thereby ensuring market liquidity.

\section{Conclusion}

Although a plethora of reforms have been initiated in Indian corporate bond markets since 1992, the size of the corporate bond market in India has remained miniscule compared to both global markets and Asian peers. In India where $95 \%$ of issuances are through private placement, reforms are required on market structure, tax related issues and streamlining issuance and settlement process so as to ensure wider investor participation. To ensure vibrancy and liquidity in bond markets, bold reforms need to be implemented so that corporates reliance on bank lending goes down and credit risks gets diversified in the economy.

\section{References}

[1] Bhaumik, S.K., S. Bose and D. Coondoo (2003) “The Emerging Indian Bond Market: Evolution, Problems and Prospects,” Journal of Global Financial Markets, Spring, 2003

[2] Bose, S., D. Coondoo and S.K. Bhaumik (1999a), “ The Indian Bond Market”, Money \& Finance, No. 8, p. $45-59$.

[3] Bose, S. and D. Coondoo (2003). A Study of the Indian Corporate Bond Market

[4] Hakansson, N. (1999), "The Role of a Corporate Bond Market in an Economy--and in Avoiding Crises," China Accounting and Finance Review , 1, No. 1, March 1999, 105-114 (Chinese version 98-104)

[5] Jin, Ngiam Kee and L. Loh (2002), "Developing a Viable Corporate Bond Market: The Singapore Experience", Economics and Finance No. 2 (2002), Institute of Southeast Asian Studies.

[6] Patil, R.H. (2001), "Broadbasing and Deepening the Bond Market in India", Wharton Financial Institutions Center Working Paper No. 01-32.

[7] Reserve Bank of India (CDS) (2011), Guidelines on Credit Default Swaps (CDS) for Corporate Bonds

[8] Reddy, Y.V. (2002), "Issues and Challenges in the Development of the Debt Market in India", BIS Papers No.11. 